\title{
ANALISIS KEUNTUNGAN USAHA TANI CENGKEH (STUDI KASUS DESA SULUUN RAYA)
}

\author{
Heince A. A. Lolowang \\ Vicky V. J. Palenewen \\ Arie D. P. Mirah
}

\begin{abstract}
ABSTRAK
This study aims to find out how much benefit the clove farmers got and how much Break Event Point (BEP) in volume and price of production were obtained by clove farmers. The research was conducted by colecting primary data through interviews using a structured simple questionnaire. Interviews were conducted in the Suluun Raya Village, Sub-district of Suluun Tareran. Total samples are 30 respondents. It has selected intentionally (purposive sampling). To achieve the research objectives, the indicator analysis used the analysis of production, cost, revenue and profit. Total production of cloves from 30 respondents in the Village of Suluun Raya was 33,020 $\mathrm{kg}$ with an average production of 1,100.6 $\mathrm{kg}$, for a total cost of IDR 1,587,078,500, with an average of IDR 52,902,617, for a total revenue of IDR 3.22865 billion with an average of IDR 107,621,666.7, and for a total profit of IDR 1,699,232,967 with an average of IDR 54.71905 million. Clove businesses in the Village of Suluun Raya has given benefits to farmers where the value of average of Revenue-Cost Ratio obtained 1.80. Thus clove farm in the village of Suluun Raya was very profitable. The Break Event Point volume of production was reached when the production rate of $542.942 \mathrm{~kg}$. Average production volume of clove farmers was $1101 \mathrm{Kg}$ means that clove businesses profitable for farmers. The Break Event Point was reached when the price of production of IDR 48 050/kg. Average price of cloves of IDR 97 433/ $\mathrm{kg}$ means that the price of cloves in the Village of Suluun Raya profitable for farmers.
\end{abstract}

Keywords : Clove farming, R/C Ratio, Break Event Point of volume and price of production, Suluun Raya Village, South Minahasa District

\begin{abstract}
ABSTRAK
Penelitian ini bertujuan untuk mengetahui besar keuntungkan yang diperoleh petani cengkeh dan berapa besar Break Event Point (BEP) dari segi volume dan harga produksi petani cengkeh. Penelitian dilakukan dengan metode survei/wawancara menggunakan kuesioner sederhana terstruktur, wawancara dilakukan di Desa Suluun Raya, Kecamatan Suluun Tareran, Minahasa Selatan. Jumlah sampel sebanyak 30 responden yang ditentukan secara sengaja (purposive sampling). Untuk mencapai tujuan penelitian maka analisis yang digunakan berupa analisis produksi, biaya, penerimaan dan keuntungan. Total produksi cengkeh dari 30 responden di Desa Suluun Raya sebanyak 33.020 Kg dengan produksi rata rata $1.100,6 \mathrm{Kg}$, untuk total biaya $\mathrm{Rp} 1.587 .078 .500$, dengan rata rata Rp. 52.902.617, untuk total penerimaan Rp. 3.228.650.000 dengan rata rata Rp. 107.621.666,7, dan untuk total keuntungan Rp. 1.699.232.967 dengan rata rata Rp. 54.719.050. Usaha cengkeh di Desa Suluun Raya memberikan keuntungan kepada petani dilihat dari nilai perbandingan antara penerimaan dan biaya $(\mathrm{R} / \mathrm{C})$ dimana nilai rata - rata Revenue Cost Ratio yang diperoleh 1,80. Secara teori bila nilai $\mathrm{R} / \mathrm{C}>1$ maka usaha cengkeh dikatakan menguntungkan. Dengan demikian usaha tani cengkeh di Desa Suluun Raya sangat menguntungkan. Hasil perhitungan untuk Break Event Point volume produksi menunjukan titik impas tercapai bila tingkat produksi 542,942 kg. Rata - rata volume produksi petani cengkeh yaitu $1101 \mathrm{Kg}$ artinya usaha cengkeh di Desa Suluun Raya dari sisi Volume Produksi menguntungkan petani. Hasil perhitungan untuk Break Event Point Harga produksi menunjukan nilai sebesarRp. 48.050, artinya titik impas tercapai bila harga produksi $48.050 \mathrm{Rp} / \mathrm{kg}$. Dari hasil penelitian rata - rata harga cengkeh yaitu Rp. 97.433/kg artinya harga cengkeh di Desa Suluun Raya menguntungkan bagi petani.
\end{abstract}

Kata Kunci: Usaha Tani Cengkeh, Revenue-Cost Ratio, Break Event Point (Volume dan Harga Produksi), Desa Suluun Raya, Kabupaten Minahasa Selatan 


\section{PENDAHULUAN}

Sektor pertanian di Indonesia merupakan sektor yang cukup tangguh dibandingkan dengan sektor lainnya. Hal tersebut telah teruji saat indonesia dilanda krisis ekonomi. Produk dari sektor pertanian justru menjadi salah satu sumber pendapatan devisa bagi negara. Umumnya, komoditas tersebut berasal dari perkebunan, salah satunya adalah produk perkebunan cengkeh.

Menurut Muljana, (2002) komoditi cengkeh (Syzygium aromaticum L) merupakan salah satu komoditi perkebunan yang memberikan kontribusi terhadap perekonomian Negara, tidak kurang dari industri kecil sampai besar yang meliputi industri-industri pabrik rokok, kosmetika, parfum, maupun rempah rempah sangat membutuhkan komoditas ini. Menurut Tjionger's (2010) selain untuk memenuhi kebutuhan dalam negeri yang semakin meningkat, komoditas cengkeh dari Indonesia juga ditujukan untuk memenuhi permintaan pasar luar negeri. Dulu sekitar tahun 1980 harga cengkeh sempat meningkat tajam. Saat cengkeh dibeli dengan harga tinggi, akibat tingginya permintaan dan terbatasnya produksi, petani meningkatkan produksinya. Ini mengakibatkan terjadi kelebihan produksi yang mencapai hampir 120.000 ton/tahun (terjadi sekitar tahun 1990-an). Padahal kebutuhan bahan baku pabrik rokok hanya mencapai 70.000 - 80.000 ton/tahunnya "ini menyebabkan harga merosot tak terkendali,"

Terlihat dengan jelas, ketika itu posisi tawar pabrik rokok jauh lebih tinggi dibandingkan posisi tawar petani. Karena terjadinya kelebihan suplai dan harga yang rendah, sehingga petani enggan untuk mengelola kebun cengkehnya. Belum puas petani merasakan nikmatnya harga cengkeh yang melonjak tinggi, pemerintah pada tahun 2002 meletakkan cukai rokok yang tinggi. Dalam APBN dianggarkan sekitar Rp 27 Trilyun diperoleh dari cukai rokok. Adanya ketergantungan pemerintah yang cukup tinggi terhadap pemasukan dari cukai rokok ini, menyebabkan posisi tawar pabrik rokok kembali naik. Mereka menuntut pemerintah mengizinkan impor cengkeh, yang harganya jauh lebih murah dibandingkan cengkeh lokal. Di samping itu, temuan dan inovasi baru pabrik rokok yang mampu menciptakan cengkeh tiruan juga ikut memperparah posisi tawar cengkeh lokal di pasaran.

Desa Suluun Raya merupakan sentra Produksi Cengkeh di Kabupaten Minahasa Selatan termasuk juga di Provinsi Sulawesi Utara, rata rata masyarakat berprofesi sebagai Petani dan umumnya petani cengkeh, Perubahan Iklim, umur tanaman cengkeh serta kondisi tanah membuat produktivitas tanaman cengkeh mengalami penurunan, biaya produksi yang makin mahal dan tenaga kerja yang makin sedikit serta harga cengkeh yang berfluktuasi di saat panen, menimbulkan permasalahan tersendiri bagi petani cengkeh

\section{Tujuan Penelitian}

Berdasarkan latar belakang dan permasalahan yang telah dikemukakan penelitian ini bertujuan untuk: 
1. Menghitung keuntungan dalam berusaha tani cengkeh

2. Menghitung break event point jumlah produksi dan harga, usaha tani cengkeh di Desa Suluun Raya Kecamatan Suluun Tareran Kabupaten Minahasa Selatan, Provinsi Sulawesi Utara.

\section{METODE PENELITIAN}

\section{Tempat dan Waktu Penelitian}

Penelitian dilaksanakan di Desa Suluun Raya Kecamatan Suluun Tareran Kabupaten Minahasa Selatan. Lokasi penelitian dilakukan secara sengaja, dengan pertimbangan Desa Suluun Raya merupakan sentra produksi cengkeh dan memiliki lahan usaha tani cengkeh terluas di Kecamatan Suluun Tareran, penelitian ini dilaksanakan pada bulan Mei sampai Juli 2016.

\section{Pengumpulan Data}

Data yang digunakan dalam penelitian ini bersumber dari data primer dan data sekunder. Pengumpulan data primer dilakukan dengan cara wawancara langsung dengan menggunakan daftar pertanyaan (quessionaire), sedangkan data sekunder diperoleh dari literature-literatur dan instansi yang ada kaitannya dengan penelitian ini

\section{Penentuan Responden}

Responden dalam penelitian ini adalah petani yang berusaha tani cengkeh yang mempunyai lahan minimal $1 \mathrm{Ha}$. Pengambilan sampel dilakukan dengan metode Purposive Sampling, sebanyak 30 responden.

\section{Analisis Data}

Untuk mencapai tujuan penelitian ini digunakan analisis deskriptif, analisis keuntungan, analisis break event point dan analisis regresi linier berganda.

1. Untuk menjawab tujuan pertama digunaka Analisis Keuntungan.

$$
\pi=\mathrm{TR}-\mathrm{TC}
$$

Keterangan :

$$
\begin{aligned}
\pi= & \text { Profit (Keuntungan) } \\
\mathrm{TR}= & \text { Total Revenue (Total Penerimaan) } \\
\mathrm{TC}= & \text { Total Cost (Total Biaya yang } \\
& \text { dikorbankan). }
\end{aligned}
$$

2. Untuk menjawab tujuan kedua digunakan Analisis Break Event Point:

BEP Harga Produksi $=\frac{\text { Total Biaya Produksi }}{\text { Volume Produksi }}$

BEP Volume Produksi $=\frac{\text { Total Biaya Produksi }}{\text { Harga Produksi }}$ 


\section{HASIL DAN PEMBAHASAN}

\section{Karakterisik Responden}

Keadaan Usahatani cengkeh di desa suluun raya sangat berkaitan dengan karakteristik petani. Karakteristik petani responden merupakan ciri ciri yang dimiliki oleh setiap responden yang berhubungan dengan usahatani yang dikelolanya, meliputi tingkat pendidikan, umur, jumlah tanggungan dan besaran kepemilikan lahan (luas lahan).

\section{Tingkat Pendidikan}

Prosentase terbesar dari tingkat pendidikan responden yaitu SMA, sebesar $60 \%$. Hal ini membuktikan bahwa tingkat pendidikan responden mempengaruhi kemampuan dan keterampilan petani dalam hal menyerap informasi yang berkaitan dengan usahataninya. Semakin tinggi tingkat pendidikan petani pemikirannya akan semakin bertambah luas terhadap suatu inovasi baru, petani berpendidikan tinggi akan lebih mudah menerima, menerapkan bahkan mengembangkannya dibanding dengan petani yang berpendidikan lebih rendah. Petani di Desa Suluun Raya telah memiliki tingkat pendidikan yang telah maju, sehingga dapat menerapkan teknologi untuk usahatani.

\section{Umur Responden}

Prosentase terbesar dari umur petani responden berusia $40 \mathrm{~s} / \mathrm{d} 49$ tahun dengan prosentase $46,7 \%$, ini menunjukkan kisaran umur petani dalam usia produktif $15-64$ tahun (BPS 2011).

\section{Jumlah Tanggungan Keluarga}

Prosentase terbesar dari jumlah tanggungan keluarga petani responden sebesar 2 jiwa dengan prosentase 73,3\%, jumlah tanggungan merupakan salah satu faktor yang dapat mempengaruhi biaya usahatani.

\section{Luas Lahan}

Prosentase terbesar dari kepemilikan lahan dari petani responden adalah petani responden yang memiliki lahan sebesar 1 2 ha dengan prosentase $57, \%$, luas lahan merupakan salah satu faktor yang akan mempengaruhi penerimaan usahatani.

\section{Analisis Keuntungan}

Total produksi cengkeh dari 30 responden di Desa Suluun Raya sebanyak $33.020 \mathrm{Kg}$ dengan produksi rata rata 1.100,6

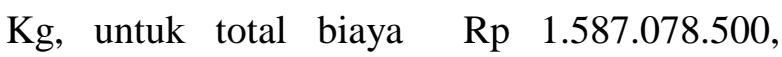
dengan rata rata $\mathrm{Rp}$. 52.902.617, untuk total penerimaan Rp. 3.228.650.000 dengan rata rata Rp. 107.621.666,7, dan untuk total keuntungan Rp. 1.699.232.967 dengan rata rata $\mathrm{Rp}$. 54.719.050.

Usaha cengkeh di Desa Suluun Raya memberikan keuntungan kepada petani dilihat dari nilai perbandingan antara penerimaan dan biaya $(\mathrm{R} / \mathrm{C})$ dimana nilai rata - rata Revenue Cost Ratio yang diperoleh 1,80 yang secara teori bila nilai $\mathrm{R} / \mathrm{C}>1$ maka usaha cengkeh dapat dikatakan menguntungkan.

Keuntungan adalah selisih antara penerimaan dan total biaya. Berdasarkan hasil penelitian rata - rata keuntungan petani cengkeh perperiode adalah Rp. 54.813.967 dapat dilihat pada Tabel 1. 
Tabel 1. Rata - rata penerimaan, biaya dan keuntungan petani cengkeh yang diperoleh saat panen

\begin{tabular}{ccccc}
\hline \multirow{2}{*}{ Data } & \multicolumn{3}{c}{ Rata - rata $(\mathrm{Rp})$} & \multirow{2}{*}{ Nilai R/C } \\
\cline { 2 - 4 } & Penerimaan & Biaya & Keuntungan & \\
\hline Panen & $107.621 .666,70$ & 52.807 .700 & 54.813 .967 & 1,8 \\
\hline
\end{tabular}

\section{Analisis Break Event Point}

Metode ini mengukur titik impas dalam usahatani cengkeh, hasil perhitungan untuk Break Event Point volume produksi menunjukan nilai sebesar $33.020 \mathrm{Kg}$ titik impas tercapai bila tingkat produksi 542,942 $\mathrm{kg}$. Artinya usaha hanya kembali modal dengan volume produksi $542,942 \mathrm{Kg}$ dan volume produksi kurang dari $542,942 \mathrm{Kg}$ usaha mengalami kerugian, rata - rata volume produksi yaitu $1101 \mathrm{Kg}$ artinya usaha cengkeh di Desa Suluun Raya dari sisi Volume Produksi menguntungkan petani. Hasil perhitungan untuk Break Event Point Harga produksi menunjukan nilai sebesarRp. 48.050 titik impas tercapai bila harga produksi $48.050 \mathrm{Rp} / \mathrm{kg}$. Artinya usaha hanya kembali modal bila harga produksi Rp $48.050 / \mathrm{kg}$. Dari hasil penelitian rata - rata harga cengkeh yaitu Rp. $97.433 / \mathrm{kg}$ artinya harga cengkeh di Desa Suluun Raya menguntungkan bagi petani.

\section{KESIMPULAN DAN SARAN}

\section{Kesimpulan}

Berdasarkan hasil analisis maka kesimpulan dari penelitian ini adalah :

1. Hasil penelitian menunjukkan bahwa hasil perhitungan dengan menggunakan metode analisis keuntungan membuktikan bahwa usahatani cengkeh menguntungkan dan dilihat dari nilai rata - rata R/C perpetani adalah 1,80 dan hasil perhitungan break event point menunjukan bahwa petani cengkeh mendapatkan keuntungan.
2. Luas lahan, Jumlah pohon, tidak mempengaruhi secara nyata terhadap keuntungan karena Luas lahan tidak sepenuhnya dipergunakan untuk tanaman cengkeh, Jumlah pohon tidak mempengaruhi secara nyata terhadap keuntungan karena perbedaan jumlah produksi masing masing pohon, jumlah produksi dan harga jual berpengaruh sangat nyata terhadap keuntungan, biaya tetap tidak berpengaruh nyata terhadap keuntungan sedangkan biaya variabel sangat berpengaruh nyata terhadap keuntungan.

3. Berdasarkan Peraturan Gubernur Nomor 37 Tahun 2015 tentang penetapan upah minimum Provinsi Sulawesi Utara yaitu Rp. 2.400.000 jika dibandingkan dengan pendapatan rata - rata petani Cengkeh di daerah penelitian masih lebih tinggi dari upah minimum provinsi (UMP) yaitu 54.719.050 per panen dalam satu Tahun jika Panen dibagi dalam waktu 12 (dua belas) bulan maka pendapatan petani cengkeh di daerah penelitian Rp. 4.559.920 per bulan

\section{Saran}

Petani sebaiknya melakukan penanaman kembali atas lahan lahan yang masih kosong atau yang masih bisa ditanami, peremajaan tanaman cengkeh yang sudah tidak produktif, Jaminan harga dari pemerintah akan sangat mempengaruhi usaha tani cengkeh 


\section{DAFTAR PUSTAKA}

Astuty Am, Yuni, 2016. Analisis kelayakan usahatani cengkeh dan kontribusinya terhadap pendapatan petani di Kabupaten Trenggalek http://repository.unej.ac.id/handle/123 456789/74606. Diakses pada 20 Agustus 2016

Babeja.com.November 2013. Hitung Kelayakan Usaha Pertanian. www.babeja.com Diakses pada 20 Agustus 2016

Badan Penelitian dan Pengembangan Pertanian Departemen Pertanian 2005, Prospek dan Arah Pengembangan agribisnis cengkeh

Badan Pusat Statistik Kabupaten Minahasa Selatan. 2015. Data Statistik Kabupaten Minahasa Selatan Dalam Angka 2015.
Duwi, 2015. Analisis Regresi Linier Berganda. http//; dwikonsultan. blogspot.co.id diakses tanggal 27 Agustus 2016.

Fadli, SE, 2016. Analisis Regresi Linier Berganda. http//dawaisimfoni. wordpress.com diakses tanggal 27 Juli 2016

Mubyarto, 2004. Pengantar Ekonomi Pertanian. Penerbit PLP3ES Press. Jakarta.

Tjionger's, 2010. Mempercepat Panen Raya Cengkeh. Hhtp://parwark. Blogsopt, com /2010/04/mempercepat-panenraya-cengkeh. Html. Diakses pada tanggal 27 Juli 2016

Wahyu Muljana, 2002. Cara Praktis Bercocok Tanam cengkeh. Aneka Ilmu Semarang. 